\title{
Machiavelli in the Lab
}

Citation for published version (APA):

Penders, B. (2017). Machiavelli in the Lab: Publish and Perish: Research on Research and Researchers. Accountability in Research-Policies and Quality Assurance, 24(1), 60-63. https://doi.org/10.1080/08989621.2016.1225499

Document status and date:

Published: 02/01/2017

DOI:

10.1080/08989621.2016.1225499

Document Version:

Publisher's PDF, also known as Version of record

Document license:
Taverne

\section{Please check the document version of this publication:}

- A submitted manuscript is the version of the article upon submission and before peer-review. There can be important differences between the submitted version and the official published version of record.

People interested in the research are advised to contact the author for the final version of the publication, or visit the DOI to the publisher's website.

- The final author version and the galley proof are versions of the publication after peer review.

- The final published version features the final layout of the paper including the volume, issue and page numbers.

Link to publication

\footnotetext{
General rights rights.

- You may freely distribute the URL identifying the publication in the public portal. please follow below link for the End User Agreement:

www.umlib.nl/taverne-license

Take down policy

If you believe that this document breaches copyright please contact us at:

repository@maastrichtuniversity.nl

providing details and we will investigate your claim.
}

Copyright and moral rights for the publications made accessible in the public portal are retained by the authors and/or other copyright owners and it is a condition of accessing publications that users recognise and abide by the legal requirements associated with these

- Users may download and print one copy of any publication from the public portal for the purpose of private study or research.

- You may not further distribute the material or use it for any profit-making activity or commercial gain

If the publication is distributed under the terms of Article $25 \mathrm{fa}$ of the Dutch Copyright Act, indicated by the "Taverne" license above, 


\section{BOOK REVIEW}

\section{Machiavelli in the Lab}

\section{Publish and Perish: Research on Research and Researchers by Joeri K. Tijdink. Amsterdam: Free University of Amsterdam, 2016.}

Confronted with a credible and potent rival, Claire Underwood reassures her husband that they will prevail: "We are willing to go one step further than everyone else" (S04E07). Stars of the Netflix' series House of Cards, the Underwoods are contemporary equivalents to Machiavelli, plotting and maneuvering their way into power. Though highly entertaining, they are prototypical rotten apples, evil geniuses winning the game by breaking the rules. Their rot is visible to everyone who watches House of Cards, yet remains opaque to most of those populating its fictional universe. Generally, rotten apples are only widely recognizable as such after exposure. For this reason, and because of the fact that pressure (e.g., to acquire and publish, in the context of science) is a part of nearly all professional practices, a focus on the individuals, rather than the system, is widely considered debatable (Anderson, Martinson, and De Vries, 2007).

Attempting to convince us otherwise, in the less fictional but equally dramatic world of contemporary science, Joeri Tijdink tests new tools to identify rotten apples before serious transgressions take place. Equipped with methodological tools drawn from, amongst others, (mental) health science and psychiatry, his focus lies firmly on the individual scientist: her and his emotions, frustrations, stress, and misbehaviors. Through a series of studies, Tijdink paints the picture of scientists confronted with pressure, which translates into stress; stress then leads to risky behavior, especially in those psychologically prone to such behaviors to begin with. Risky behavior in science includes crossing the line between proper science and questionable research practices, and sometimes blatant fraud. Tijdink works towards identifying those who are most prone to such behavior: to filter out the Frank Underwoods of the scientific world.

Publish and Perish: Research on Research and Researchers (2016) is the result of a 4 year long empirical mixed methods study on research integrity and research misconduct by Joeri Tijdink, a Dutch psychiatrist. It chronicles the relationship between publication pressure, psychological characteristics of individual researchers and research misconduct. The majority of Tijdink's work is quantitative; more specifically, it consists of association studies between self-reported misconduct frequencies and other variables. A notable exception is chapter 6, in which Tijdink reports the results of focus group discussion on publication pressure.

Tijdink starts from the position that scientific work is susceptible to bias because of the heavy workload of those working in academia. As a consequence, this puts the validity and credibility of science at risk. His explicit focus of research is publication culture, articulated as a context in which pressure, corruption, fraud, and waste shape scientific work (p. 10-11). The book accordingly focuses on what could go wrong and does go wrong: scientific misconduct, questionable research practices, and detrimental psychological characteristics of individual researchers associated with both. 
One of the key tools used is the publication pressure questionnaire (PPQ). Tijdink and colleagues have developed the PPQ based upon a hypothesized "theory of publication pressure" (p. 22), which is not explained further. The tool is rooted firmly in psychological and health science models, contributing to a medicalized view of publication pressure as stress. Interestingly, Tijdink explains that an initial test of the PPQ showed that it measured more than just publication pressure (p. 27). To account for this difference, the object of study was rhetorically repositioned as publication culture. Additionally, Tijdink had Dutch medical professors fill out existing burnout questionnaires to demonstrate job-related pressure. While young researchers perceive enormous pressure, the archetypical medical professor experiencing the lowest amount of burnout symptoms and publication pressure is male, has a high h-index, has no children living at home, nor a partner (and if such a partner exists anyway, she ought to provide unconditional support), has held his chair for a long time, and experiences a lot of power to shape his or her work and surroundings. In a subsequent study in Flemish medical professionals, Tijdink took this further and also invited these Flemish medical professionals to score the frequency of specific acts of research misconduct-a list of about two dozen examples ranging from plagiarism (three penalty points) to unwarranted authorship (one penalty point). Tijdink positions publication pressure as a form of stress, which in turn leads to risky behavior (p. 90). Again, those most "risky" are young and early career researchers.

Using a different version of the research misbehavior severity score and a series of questionnaires designed to assess psychological traits, Tijdink studied the relationship between research misbehavior, personality, and publication pressure. Despite a number of them tested, Machiavellianism ${ }^{1}$ was the only personality trait significantly associated with misbehavior. This relationship was stronger in the case of higher academic positions and high publication pressure. Tijdink's focus on the individual, lead him to conclude that "the results may inform those involved in recruitment of scientific personnel ... scientific quality and integrity monitoring and ... institutional research integrity policy and for responsible conduct of research training" (p. 149). In a tongue-and-cheek chapter originally written for (but not accepted by) the BMJ Christmas issue, he clustered all responders into three personality groups: perfectionists, ideal-son-in-laws, and the "sneaky grandiose." In the last category, members' personality may predispose them to risky behavior and even misconduct, while membership of the first category severely reduces chances of ever becoming a full professor. He translates these findings into an addition to the DSM-V for publiphillia impactfactoris and an advice to modify hiring behavior to reduce the likelihood of research misconduct.

Diverting from quantitative studies and in pursuit of a deeper understanding of publication pressure, Tijdink organized a series of 12 focus groups at Dutch university medical centers. From these groups, the following eight themes emerged as most relevant to professionals: (1) research funding, (2) authorship and sequence, (3) quality vs. quantity, (4) publication pressure, (5) misconduct and integrity, (6) publication bias, (7) impact factor, and (8) prestige and recognition. Many of these themes were not represented in the publication pressure questionnaires-although they are hardly new for those critically engaging with research integrity. Despite the richness of this study, Tijdink clearly classifies it as inferior to his quantitative approach: "[S] uch studies lack advantages of quantitative studies, such as precise measures of effect sizes and variation”

\footnotetext{
${ }^{1}$ Tijdink defines Machiavellianims as "a person's tendency to be unemotional, detached from conventional morality and hence inclined to deceive and manipulate others, to focus on unmitigated achievement and to give high priority to their own performances" (p. 140).
} 
(p. 114). In line with this, the voices of research participants are hidden in tables at the end of the chapter, rather than used as demonstrations and empirical support throughout.

Tijdink acknowledges that he took a psychiatric perspective in his research on research and researchers' culture (p. 186). Culture, however, is conceptualized by Tijdink initially as anything more than pressure (to account for what his questionnaire was measuring) and later as decisions by individuals and external sources of bias, making his study of publication culture and research integrity a narrative of risky behavior and mental pathologies present in individuals. Tijdink, as well as his respondents, are cynical about the state of science. The sole qualitative study in the book provides the required context and empirical richness to make the cold and detached measurements come alive. To be emotionally exhausted, to feel pressured and to live a professional life on the leash of output-driven audits is difficult to capture in tables.

Tijdink's questionnaires on research misbehavior award three penalty points to admitted fraud and one penalty point to "minor" questionable research practices. The arbitrariness of such scoring mechanisms combined with the expected underrepresentation of self-admitted misbehavior and the fact that a few focus groups already showed that the questionnaire is, at best, incomplete, calls into question the value of a scoring approach to the study of research integrity. Despite the subtitle Research on Research and Researchers, all fields associated with the study of science and scientific practices are close to absent. On the quantitative side, these include scientometrics and the nascent science of team science; on the qualitative side, these are the philosophy, sociology and history of science, research ethics, and science and technology studies. Throughout the book, critical discussions of publication pressure, evaluation cultures, research integrity, and its study are supported mostly by references to editorials in medical journals, rather than peer reviewed articles.

Publish and Perish: Research on Research and Researchers presents us with a view of research integrity as being about adhering to methodological rules, in which bias is a pathology invading an otherwise pure science of which the boundaries are clear and trespasses of that boundary can be scored. Taken to the extreme, Tijdink's focus on the individual could lead to perceiving scientists as if they are all dormant Frank Underwoods plotting their own little coups, which could only add to the layer of individual evaluation currently corrupting the scientific landscape. Yes, science is imperfect, just like politics of House of Cards. Its stars are not evil geniuses, though. Research integrity is about morality as much as about methodology, and the boundary between the two is fuzzy at best (De Vries, Anderson, and Martinson, 2006; Penders, Vos, and Horstman, 2009); science was never pure (Shapin, 2010) and bias was never absent. In addition, questionable research practices are hardly caught in a list-however long, detailed, and sophisticated. The organization and content of science is a moving target-and so are boundaries of proper science. For instance, with a shifting focus to impact, scientists have found new ways to game the system and come out on top (cf. Biagioli, 2016).

In a choice between "the system corrupts the people" vs. "the people corrupt the system," Tijdink heavily leans towards the latter. Nevertheless, numbers are powerful rhetorical tools. Tijdink's contribution to the scientific literature on research integrity is making the problem visible and communicable, a public legitimation of the work we all do-regardless of our disciplinary or methodological approach. His book and the published and unpublished studies it contains are above all else a tool to build credibility and relevance for new and in-depth work on research integrity, taking into account its plurality, situated character, and the fact that scientific practice and our understanding of proper science will forever co-evolve. 


\section{Bart Penders, Ph.D. \\ Department of Health, Ethics \& Society, School of Public Health \& Primary Care (CAPHRI), Maastricht University, Maastricht, The Netherlands \\ Qb.penders@maastrichtuniversity.nl \\ (C) 2017 Taylor \& Francis \\ http://dx.doi.org/10.1080/08989621.2016.1225499}

\section{References}

Anderson, M. S., B. C. Martinson, and R. De Vries. 2007. Normative dissonance in science: Results from a national survey of U.S. Scientists. Journal of Empirical Research on Human Research Ethics 2:3-14. doi:10.1525/jer.2007.2.4.3.

Biagioli, M. 2016. Watch out for cheats in citation game. Nature 535:201. doi:10.1038/535201a.

De Vries, R., M. S. Anderson, and B. C. Martinson. 2006. Normal misbehavior: Scientists talk about the ethics of research. Journal of Empirical Research on Human Research Ethics 1:43-50. doi:10.1525/ jer.2006.1.1.43.

Penders, B., R. Vos, and K. Horstman. 2009. A question of style: Method, integrity and the meaning of proper science. Endeavour 33:93-98. doi:10.1016/j.endeavour.2009.07.001.

Shapin, S. 2010. Never pure: Historical studies of science as if it was produced by people with bodies, situated in time, space, culture, and society, and struggling for credibility and authority. Baltimore, MD: Johns Hopkins University Press.

Tijdink, J. K. 2016. Publish and perish: Research on research and researchers. Amsterdam: Free University of Amsterdam. 